reports on the work of the seven associations and the Commission were presented, it was on all sides agreed that the scientific discussions had been most useful and successful, and that the Assembly had been as valuable as it was harmonious. Apart from the exchange and clarification of linowledge by the reading and discussion of scientific reports and papers (many of which had been circulated in full or in abstract beforehand), the associations were able to perform useful business in arranging for the continuance, in some cases with useful modifications or extensions, of international enterprises of geophysical importance, which they organize or support. Valuable and instructive scientific excursions, and visits to American scientific institutions, also took place during or before the Assembly.

Personal meetings and discussions between fellow. workers in geophysics, from different countries, form another important contribution which such interna. tional assemblies afford to scientific progress. These wero facilitated not only by the formal meetings, but also by the public and private hospitality which were dispensed to delegates, with the proverbial American warmth and generosity. Recollection of the kindness thus received from our American hosts will long be treasured in our memories.

Tho president and general secretary of the Union were honoured during the Assembly by the conferment of the doctorate of the George Washington University.

Tho Pan American Institute of Geography and History (director, Dr. P. C. Sánchey, Mexico) co. operated with the Union and held threo meotings of its executive committee during the Assembly, at which many matters of interest to geodesists and geophysicists wero discussed. S. Chapsian.

\title{
WORK OF THE WATER POLLUTION RESEARCH BOARD
}

\begin{abstract}
A PART of the programme arranged for the A Conference of Delegates of Corresponding Socioties during the Dundeo meeting of the British Association was a discussion on river pollution. Sir Robert Robertson, chairman of the Water Pollution Board of the Department of Scientific and Industrisl Research, had prepared a statement of the work of the Board for presentation to the discussion, from which the following account has been prepared. Details will be found in the reports of the Board published by H.M. Stationery Office.
\end{abstract}

\section{Trade Effluents}

Beet-sugar factory efluents. The ovil due to these effluents can bo avoided by passing the effluents through a biological filter, similar to that used on sewage disposal works. It is also practicable, however, to avoid the discharge of effluent by simple treatment by sedimentation, and addition of small quantities of lime so that the waters can be re-used in the factory.

Milk-faetory effuent. This effluent, which is highly polluting and may be inimical to fish-life, since it removes dissolved oxygen from the water, has been demonstrated to be capable of complete purification by two methods: that of biological filtration, in which two percolating filters in series are employed, and the sequence of the two filters is periodically changed, and by the activated sludge process. The former method has been adopted in a number of factories. Fish can livo in the treated effluents.

\section{Studies of River Pollution}

The River Tees. A river was chosen which is substantially unpolluted in its upper reaches, then polluted by sewage from a large town, and finally contaminated by sewage and trade effuents in its estuary. The Tees was formerly an important salmon river; it was found that in their progress down the Tees to the sea the smolts were poisoned in thousands. There has been no study made of a river's life-history so intensive, from the different aspects, chemical, biological, and hydrographical. In the non-tidal reaches the effects of sewage wore studied on the chemical composition, and animal and vegetable life of the river, and on the seasonal changes with respect to the self-purification of the river. Similarly, in the estuary, these effects were observed on the composition of the water and estuarine life. An interesting conclusion was reached that the hitherto unsuspected cause of the death of smolts was due to cyanide from the coke-ovens; and methods of avoiding this were suggested, and to some extent have been adopted. This intensive study of a river from source to sea may be taken as an authoritative model for future investigations of other rivers.

The Mersey Estuary. Possibly as a result of its successful investigation of the $I$ эr Tees, the Board was asked to carry out an invest on on the effect of the discharge of crude sewage from Liverpool and other towns in the district on the presumed silting-up of the estuary of the Mersey. This work, on which a comprehensive report has been made, involved nearly four years investigations by hydrographers, chemists, and biologists, and its findings, which are unequivocal, have been accepted by the interested bodies. It was found that the volume of the estuary is subject to periodical changes, but that the alleged shrinkage in the volume and hardening of the bed could not be attributed to the discharge of sewage into the estuary.

\section{WATER SUPPLy}

Tro aspects of water supply have engaged the attention of the Board : the base-exchange process for softening water, and the question of provention of contamination of drinking water by lead.

Base-exchange process. The effect of the various substances used for this process has been examined, and quantitative determinations have been made of the efficiency of the substances on the market, as well as of others, including treated natural clays. A remarkable discovery has been made whereby suitably prepared artificial resins can be used to remove both acidic and basic radicals from water.

Prevention of contamination by lead. A study of 
plumbo-solvency is being made with the object of improving largo-scale methods of treatment of water. In the meantime, an apparatus has been evolved which on being introduced into $a$ water circuit enables a quantitativo measure of the lead present in the water to be obtained.

\section{Sewage Purification}

As fundamental knowledge was wanting as to the mechanism of methods of treating sewage, such as the activated sludge process, two groups of workers have been engaged on the chemistry and biology of this problem.

The effect of the air-bubbles, which are an essen. tial part of this process, has been examined by chemical and physico-chemical methods, and tho changes which occur in the nitrogen and carbon compounds found in sewage and servage-sludge have been studied in conjunction with the enzymic nctivity of bacterial colls.

\section{ROAD DEVELOPMENT IN THE UNITED STATES}

$\mathrm{M}$ R. E. L. LEEMING, an expert on road construction, has given a description in Roads and Road Construction, of October 2, of a motor journey he made recently across the United States from Washington to San Francisco, along the Lincoln Highway. This road is now practically completed.

The first thing which strikes the oye of a road engineer, or a road user, when 'docking' at Now York, is the sight of the motor traffic speeding along the overhead 'express highway' parallel with the Hudson River and linking the busiest parts of 'downtown' with Riverside Drive, Bronx and other suburbs. For the rapid movement of people, this artery is just as important to the city as the underground railways are. In WVashington, since the economic blizzard of 1929, considerable transformation has taken place. Where streets are wide, many things are possible in the way of accommodating traffic. Thero is room for parking at the side or in the centre, and it is possible to construct an underpass of one road relative to another. Mr. Leeming saw a schemo of this kind in progress; one $d$ is boing carried beneath the other, while th urface of the junction is being arranged as a circle to link the connecting roads.

Tho Lincoln Highway connects tho east coast at Now York, where it passes beneath the Hudson River by the new Isincoln tunnel, with tho Pacific coast near Portland. The road touches Philadelphia, Pittsburgh, Fort Wayne, south of Chicago, Cedar Rapids (Iowa), thence crossing Nebraska, Wyoming, Idaho and Oregon. At Wyoming the road crosses the 'continental divide' at a height of about 7,000 feet. At Salt Lake City lie left the Lincoln Highway (U.S.30) and travelled by U.S.40 to San Francisco. Between Nebraska and Wyoming his average speed was $55 \mathrm{~m} . \mathrm{p.h}$. in his Studebaker car and his longest day's run was 610 miles. With daily mileages of $500-600$, the number of restrictions or hazards are fow. Cyclists and pedestrians aro entirely absent, while horse vehicles are very rare.

Some curious notices were observed: "Danger, slippery, beware crickets" (meaning dead grasshoppers). In some of the villages, signs were noticed, such as, "Stop when pedestrians are on the cross. walk", "No overtaking for 700 feet", and so on. Good work is being done in the States in regard to 'safety first' measures by organizing schoolchildren. Selected children are trained as leaders to act as traffic police for the purpose of conducting schoolchildren across the roads to and from school. They carry signs indicating "Stop", and every motorist oboys them. Besides preventing children from being run down on the road, it teaches them to obsorvo habits of 'safety first'. In Salt Lake City, where wide streets occur, parking is arranged with the aid of a special meter mounted on a pedestal opposite each vehiclo parked on the slant. This meter is operated by placing a nickel (2ld.) for half an hour's parking, two nickels or one dime for an hour, and two dimes for two hours. Within these periods an indicator finger is visible at the top of the meter. The meters are only employed between the hours of 9 a.m. and 6 p.m.

Mr. Leeming's journey back from the Pacific coast to Now York was made by air over a route covering the Boulder Dam, Grand Canyon, Toxas, Kansas City, St. Louis and Pittsburg. 'This trip tækes about 18 hours flying time, but compared with the journey by road, one does not acquire any intimate knowledge of the continent. The author strongly recommends a road journey across from east to west, by one of the arterial routes, U.S.30, U.S.40 or U.S.50. If it is not practical to hire or share a car, the Greyhound, a motor-bus service, is always running. These buses travel over tho wholo of the States, day and night, and one can sleep on them in very comfortable reclining chairs, if timo has to bo saved. Tho cost appears to be much less than that of the rail services. While the latter cost 90 dollars return from New York to San Francisco (without extras), the bus services cost about 65 dollars (about £14) for some 6,000 miles. These buses travel along the highways at about 50-60 m.p.h. and make very good progress.

Some indication of the programme of road develop. ment which is likely to be followed in the future is given in the General Motors Exhibition at the New York World Fair. Before making the tour, on the moving chairs of the panorama depicting the high. ways of America in 1940 gradually changing into the highways of 1960, you are shown a large map of the United States on the ceiling. By an arrangement of the lighting the existing roads are replaced by the new system of modern highroads which will cover the whole continent. Mr. Leeming was informed in Vashington that there is enough road development work progressing in the States to keep them busy for the next two generations. Taking into account the remarkable progress which America has already made in road planning, bridge construction and tho provision of flyover junctions, he has no doubt that the scheme outlined at the Vorld Fair will be brought to fruition within the period contemplated. 